\title{
PENGEMBANGAN SISTEM INFORMASI ADMINISTRASI PEMERIKSAAN PASIEN DI INSTALASI RADIOLOGI RSUD KAJEN DENGAN UNIFIED PROCESS
}

\author{
Yadanur Alim, Suhartono, Priyo Sidik Sasongko \\ Program Studi Teknik Informatika, Fakultas MIPA, Universitas Diponegoro \\ yadanur.alim22@gmail.com
}

\begin{abstract}
Kajen Regional Hospital of Pekalongan Regency has applied information technology to improve the quality of service to the patients. Radiology installation is one of the installations in Kajen Regional Hospital which was being developed computer based information system to facilitate its operations. Earlier, the staff at the Radiology Installation of Kajen Regional Hospital used numbers processing application such as Microsoft Office Excel to process the data. The growth of patient and examination of patients data in the future was a consideration for the Radiology Installation of Kajen Regional Hospital of Pekalongan Regency to develop a Administration of Examination Patient Information System in Radiology Installation of Kajen Regional Hospital which was integrated with the database system. Administration of Examination Patient Information System in Radiology Installation of Kajen Regional Hospital was developed with the Unified Process. Unified Process is included in object-oriented software development paradigm. This system was implemented using the Visual Basic.Net programming language and MySQL 5 as its DBMS. This system was tested by using black box method, namely the testing methods that test the functionality of the software without having to know the internal structure of the program. This system can help the radiology staff in managing the administrative data and making the administrative reports.
\end{abstract}

Keywords: Information System, Administration, Unified Process, Object Oriented

\section{Pendahuluan}

Berdasarkan hasil survey, Rumah Sakit Umum Daerah (RSUD) Kajen Kabupaten Pekalongan telah menerapkan Teknologi Informasi untuk meningkatkan kualitas pelayanannya terhadap para pasien. Instalasi Radiologi RSUD Kajen Kabupaten Pekalongan merupakan salah satu instalasi di RSUD Kajen Kabupaten Pekalongan yang tengah gencar dikembangkan sistem informasi berbasis komputer untuk mempermudah kegiatan operasionalnya.

Instalasi Radiologi RSUD Kajen Kabupaten Pekalongan merupakan salah satu instalasi di RSUD Kajen Kabupaten Pekalongan yang melayani kegiatan pemeriksaan radiologi seperti rontgen dan Ultrasonografi (USG). Berdasarkan hasil survey dan wawancara dengan salah satu staf medis di Instalasi Radiologi RSUD Kajen Kabupaten Pekalongan, sebelumnya para staf di Instalasi Radiologi RSUD Kajen Kabupaten Pekalongan menggunakan aplikasi pengolah angka seperti Microsoft Office Excel untuk mengelola data pasien dan pemeriksaan pasien. Sebenarnya, aplikasi pengolah angka seperti
Microsoft Office Excel sudah memenuhi kebutuhan instalasi radiologi untuk saat ini, tetapi karena pertimbangan pertumbuhan data pasien dan pemeriksaan pasien di masa yang akan datang yang dikhawatirkan suatu saat tidak dapat ditangani oleh Microsoft Office Excel maka perlu dikembangkan suatu sistem informasi yang terintegrasi dengan sistem basis data.

Unified Process merupakan salah satu software development process yang menerapkan konsep berorientasi objek yang dikembangkan oleh Ivar Jacobson, Grady Booch, dan James Rumbaugh [6]. Dengan konsep berorientasi objek, perangkat lunak mempunyai kualitas yang tinggi dan dapat diuraikan serta diskalakan. Berdasarkan pertimbangan keunggulan yang dimiliki Unified Process, maka Unified Process digunakan dalam proses pengembangan sistem informasi ini, sehingga diharapkan dapat dihasilkan perangkat lunak yang berkualitas tinggi, reusable, dan mudah untuk dipelihara. 


\section{Tinjauan Pustaka}

\section{1 Sistem Informasi}

Sistem informasi adalah kumpulan dari prosedur dan komponen yang saling berhubungan yang membentuk satu kesatuan untuk mencapai tujuan tertentu yakni mengolah data menjadi informasi sehingga lebih berguna bagi pengguna [7].

\section{2 Administrasi}

Menurut Kamus Besar Bahasa Indonesia susunan W.J.S Poerwadarminta administrasi diartikan sebagai tata usaha. Sedangkan tata usaha sendiri didefinisikan sebagai kegiatan penyelenggaraan urusan tulis menulis (keuangan dan sebagainya) dalam perusahaan (negara dan sebagainya).

\section{3 Konsep Berorientasi Objek}

Konsep berorientasi objek merupakan konsep yang membagi program menjadi objek-objek yang saling berinteraksi satu sama lain [4].

Beberapa istilah yang berkaitan dengan konsep berorientasi objek adalah [10]:

1) Class dan Objek,

Class dapat diartikan deskripsi secara umum atau cetak biru yang menggambarkan sekumpulan objek yang serupa. Sedangkan objek dapat diartikan sebagai bentuk instansiasi dari sebuah class.

2) Atribut,

Atribut adalah sesuatu yang melekat pada objek yang mendeskripsikan sifat objek atau dengan kata lain atribut merupakan sifat karakteristik yang dimiliki oleh objek.

3) Method atau Operasi,

Method adalah prosedur atau fungsi yang dimiliki suatu objek. Method mempresentasikan perilaku dari suatu objek.

4) Message,

Suatu objek berinteraksi dengan objek lainnya melalui message. Message menstimulasi method yang ditemui pada objek yang menerima message tersebut untuk dieksekusi atau dijalankan.

Konsep berorientasi objek mempunyai tiga karakteristik, yaitu [10] :

1) Enkapsulasi,

Enkapsulasi merupakan pengemasan atribut dan method dalam objek. Enkapsulasi bertujuan sebagai upaya untuk menyembunyikan informasi atau information hiding sehingga tidak dapat diakses secara bebas oleh objek lain.

2) Pewarisan,

Pewarisan merupakan bentuk sifat reuseable dalam konsep berorientasi objek, artinya suatu class dapat menurunkan atribut dan operasinya ke class yang lain.

3) Polimorfisme,

Polimorfisme merupakan suatu konsep yang memungkinkan sejumlah operasi yang memiliki perilaku berbeda untuk mempunyai nama yang sama.

\section{4 UnifiedProcess}

Unified Process merupakan salah satu software development proses yang telah mendukung konsep berorientasi objek. Unified Process menggunakan Unified Modeling Language (UML) sebagai notasi dalam menggambarkan proses pengembangan perangkat lunak.

Unified Process mempunyai tiga karakteristik utama, yaitu [7] :

1) Use Case Driven,

Maksud dari use case driven adalah bahwa use case tidak hanya merupakan alat untuk menspesifikasi kebutuhan fungsional sistem, tetapi use case juga mengarahkan semua workflow dalam proses pengembangan software.

2) Architecture Centric,

Architecture Centric berarti bahwa suatu arsitektur sistem dipergunakan sebagai suatu artifact primer untuk conceptualizing, membangun, pengelolaan, dan meningkatkan sistem dalam pembangunannya.

3) Iterative \& Incremental,

Iterative berarti bahwa proses pengembangan perangkat lunak dilakukan berulang-ulang. Sedangkan incremental berarti bahwa setiap iterasi mengacu pada pertumbuhan produk.

Dalam Unified Process, pengembangan perangkat lunak dilakukan dalam sejumlah siklus yang berkelanjutan. Setiap siklus akan berakhir pada release sebuah produk. Setiap siklus tersebut terdiri atas empat fase yang berbeda, yaitu inception, elaboration, construction, dan transition. Setiap fase dapat terdiri atas sejumlah iterasi workflow (requirement, analysis, design, implementation, dan test). Selanjutnya, workflow menentukan 
urutan aktivitas yang perlu dilakukan dan artifak apa yang harus dihasilkan. Saat pengembangan perangkat lunak beralih dari satu fase ke fase berikutnya, jumlah kerja yang dilakukan di tiap workflow juga berubah.

Pada fase inception, pekerjaan terbesar adalah requirement dan analysis. Fase elaboration menekankan pada requierement, analysis, dan sedikit design. Fase construction lebih menekankan pada design dan implementation, sedangkan fase transition penekanan beralih pada implementation dan test [2]. Gambar 1 menunjukkan hubungan antara fase dan workflow dalam Unified Process.



Gambar 1 Hubungan Fase dengan Workflow dalam Unified Process

Penjelasan tiap-tiap fase dalam Unified Process adalah sebagai berikut[6] :

1) Inception,

Inception mendefinisikan lingkup project dan mengembangkan business case untuk sistem. Fase ini terfokus pada requirement serta sedikit melakukan analisis dan design.

2) Elaboration,

Aktivitas yang dilakukan pada fase ini adalah melengkapi requirement, baik fungsional maupun nonfungsional serta melakukan analisis dan design.

3) Construction,

Construction merupakan fase pembangunan sistem. Sedikit analisis masih dapat dilakukan pada fase ini untuk melengkapi hasil analisis yang telah dihasilkan pada fase sebelumnya. Tiga workflow terakhir, yaitu design, implementasi, dan pengujian menjadi aktivitas utama dalam fase ini.

4) Transition,

Transition merupakan peralihan produk ke lingkungan user (beta release). Beta release merupakan versi baru dari perangkat lunak yang belum diuji secara penuh dari kemungkinan adanya defect atau cacat program. Sejumlah user akan mencoba produk yang telah dihasilkan dan melaporkan defect yang ditemukan. Defect akan dibetulkan dan kemudian fase ini berakhir pada release produk resmi.

Unified Process terdiri atas lima workflow. Penjelasan tiap-tiap workflow tersebut adalah sebagai berikut [6] :

1) Requirement,

Tujuan dari requirement adalah untuk menemukan dan mencapai persetujuan mengenai apa yang harus dilakukan sistem yang diungkapkan dalam bahasa user [2]. Selanjutnya, requirement sistem tersebut akan digambarkan dalam istilah use case, sehingga output dari requirement ini berupa use case model yang terdiri atas use case, aktor, GUI prototype, dan non-functional requirement [5].

2) Analysis,

Analisis bertujuan untuk menerjemahkan requirement kedalam bahasa developer dan mengidentifikasi elemen atau entitas utama dari sistem yang diperlukan untuk memenuhi user requirement [5]. Artifak-artifak yang dihasilkan dalam tahap analisis antara lain analysis class, use case realization analysis, dan analysis package.

3) Design,

Design berusaha untuk menspesifikasikan secara penuh bagaimana fungsionalitas akan diimplementasikan dengan menggunakan model yang telah dihasilkan dari workflow analisis. Artifak yang dihasilkan dalam workflow ini meliputi design subsystem, design classes, dan use case realization design [2].

Database design yang akan digunakan sebagai tempat penyimpanan data juga dibuat pada tahap ini. Database yang digunakan dalam pengembangan sistem ini adalah relational database. Relational database design merupakan mapping kedalam relational table dari setiap class dalam class diagram yang bersifat persistent. 
4) Implementation,

Implementation bertujuan untuk mentransformasikan design model ke dalam executable code. Source code program dibuat pada workflow ini.

5) Test (Pengujian)

Tujuan dari pengujian adalah untuk memastikan bahwa sistem dapat menyediakan fungsionalitas yang diperlukan. Pengujian yang dilakukan hanya pengujian secara black box, yaitu menguji fungsionalitas dari perangkat lunak, tanpa harus mengetahui struktur internal program [10]. Artifak yang dihasilkan pada workflow ini adalah test model [5].

\subsection{Unified Modelling Language}

Unified Modeling Language (UML) adalah bahasa standar yang digunakan untuk menulis blueprint perangkat lunak. UML dapat digunakan untuk memvisualisasi, menspesifikasikan, membangun, dan mendokumentasikan artifak dari sistem perangkat lunak.

UML terdiri atas tiga building block, yaitu[3] :

1) Things,

Things adalah building block berbasis objek yang utama dari UML. Things terdiri atas 4 macam, yaitu :

a) Structural Things,

Structural things adalah bagian model statis yang merepresentasikan elemen konseptual atau fisik. Jenis-jenis structural things adalah class, interface, collaboration, dan use case.

b) Behavorial Things,

Behavorial things adalah bagian dinamis dari model UML yang merepresentasikan behavior. Jenis behavorial things adalah interaction, state machine, dan activity.

c) Grouping Things,

Grouping things adalah bagian dari model UML yang berfungsi untuk mengelompokkan elemen. Satu-satunya jenis grouping things adalah package.

d) Annotational Things,

Annotational things adalah bagian penjelas dari model UML. Jenis annotational things adalah note yang digunakan untuk memberikan komentar.

2) Relationship,

Relationship merupakan building block UML yang berfungsi sebagai penghubung antar things. Jenis-jenis relationship antara lain dependency, Association, Generalization, Realization.

3) Diagram,

Diagram adalah presentasi grafis yang merupakan kombinasi antara things dan relationship. Diagram dibuat untuk memvisualisasikan sistem dari sejumlah perspektif yang berbeda, sehingga diagram merupakan proyeksi terhadap sistem. UML mempunyai tiga belas diagram. Penjelasan dari tiap-tiap diagram tersebut ditunjukkan pada Tabel 1.

Tabel 1 Nama - Nama Diagram

\begin{tabular}{|c|c|}
\hline Nama Diagram & Kegunaan \\
\hline Activity & $\begin{array}{l}\text { Behavioral prosedural } \\
\text { dan paralel }\end{array}$ \\
\hline Class & $\begin{array}{l}\text { Class, fitur, dan } \\
\text { hubungan } \\
\text { hubungannya }\end{array}$ \\
\hline Communication & $\begin{array}{l}\text { Interaksi antar objek, } \\
\text { penekanan pada jalur }\end{array}$ \\
\hline Component & $\begin{array}{l}\text { Struktur dan koneksi } \\
\text { komponen }\end{array}$ \\
\hline $\begin{array}{l}\text { Composite } \\
\text { structure }\end{array}$ & $\begin{array}{l}\text { Dekomposisi runtime } \\
\text { sebuah class }\end{array}$ \\
\hline Deployment & $\begin{array}{l}\text { Pemindahan artifak ke } \\
\text { node }\end{array}$ \\
\hline $\begin{array}{l}\text { Interaction } \\
\text { overview }\end{array}$ & $\begin{array}{l}\text { Campuran sequence } \\
\text { dan activity diagram }\end{array}$ \\
\hline Object & $\begin{array}{l}\text { Contoh konfigurasi } \\
\text { dari contoh - contoh }\end{array}$ \\
\hline Package & $\begin{array}{l}\text { Struktur hirarki } \\
\text { compile-time }\end{array}$ \\
\hline Sequence & $\begin{array}{l}\text { Interaksi antar objek, } \\
\text { penekanan } \\
\text { sequence }\end{array}$ \\
\hline State machine & $\begin{array}{l}\text { Bagaimana } \\
\text { mengubah } \\
\text { selama aktif }\end{array}$ \\
\hline Timing & $\begin{array}{l}\text { Interaksi antar objek, } \\
\text { penekanan pada timing }\end{array}$ \\
\hline Use Case & $\begin{array}{l}\text { Bagaimana pengguna } \\
\text { berinteraksi }\end{array}$ \\
\hline
\end{tabular}




\section{6 Object Relational Mapping (ORM)}

Object Relational Mapping (ORM) adalah suatu metode untuk memetakan objek menjadi tabel dalam relational database [1]. Konsep mapping objek ke relational database yang digunakan yaitu konsep pemetaan dasar dan pemetaan hubungan objek [1].

\section{7 Visual Basic .Net dan MySQL}

Visual Basic.Net merupakan bahasa pemrograman untuk membuat aplikasi berbasis windows. Visual Basic .Net dibangun di atas fondasi Framework .Net. Visual Basic .Net juga sudah mendukung pemrograman berorientasi objek [8].

MySQL adalah Relational Database Management System (RDBMS) yang didistribusikan secara gratis dibawah lisensi GPL (General Public License) dan bersifat open source [12].

\section{Definisi Kebutuhan, Analisis, dan Perancangan}

\subsection{Definisi Kebutuhan}

Sistem Informasi Administrasi Pemeriksaan Pasien ini dikembangkan untuk diimplementasikan di Instalasi Radiologi RSUD Kajen Kabupaten Pekalongan. Sistem ini memiliki tiga buah otoritas yaitu operator, kepala instalasi, dan administrator. Sistem ini dapat melayani pendaftaran pasien, menyusun rencana pemeriksaan pasien, menyimpan hasil diagnosa pemeriksaan pasien, menghitung tagihan pemeriksaan, dan menyusun laporan.

Sistem ini dibuat untuk mempermudah pekerjaan para staf di Instalasi Radiologi RSUD
Kajen Kabupaten Pekalongan dalam mengelola data administrasi pasien, sehingga dapat meningkatkan kinerja pelayanan terhadap para pasien. Gambaran umum sistem yang dikembangkan dapat dilihat pada Gambar 2.



Prosedur atau alur kegiatan pemeriksaan pasien di Instalasi Radiologi RSUD Kajen Kabupaten Pekalongan dapat dilihat pada diagram aktivitas Gambar 3.

Diagram system use case digunakan untuk menggambarkan sistem yang dikembangkan. Diagram system use case dari Sistem Informasi Administrasi Pemeriksaan Pasien di Instalasi Radiologi RSUD Kajen Kabupaten Pekalongan dapat dilihat pada Gambar 4. 


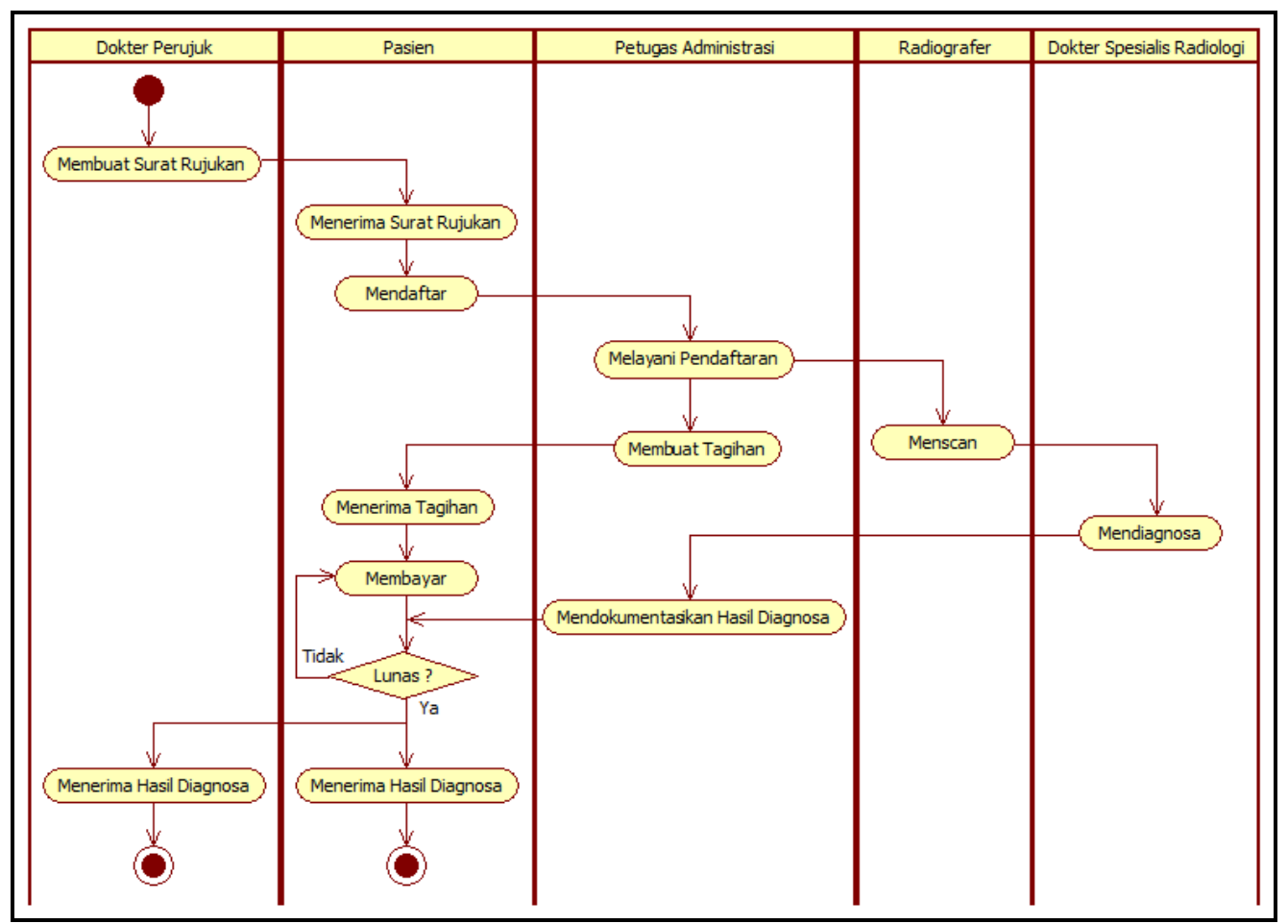

Gambar 3 Diagram Aktivitas Pemeriksaan Pasien

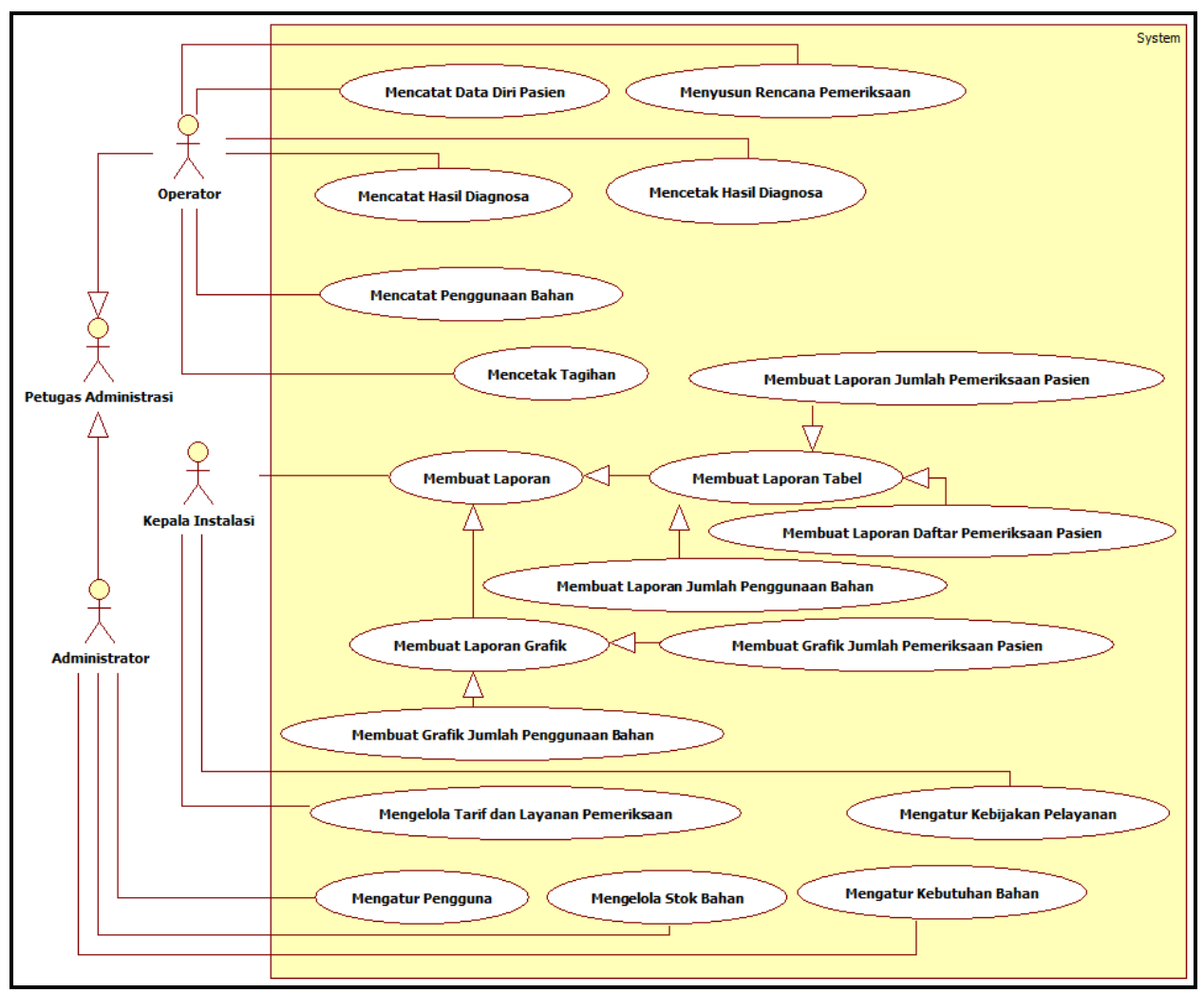

Gambar 4 Diagram System Use Case 


\subsection{Analisis}

Setiap use case pada tahap analisis direalisasikan dengan menggunakan analysis class diagram. Realisasi use case "Mencatat Data Diri Pasien" ditunjukkan dengan analysis class diagram pada Gambar 5.

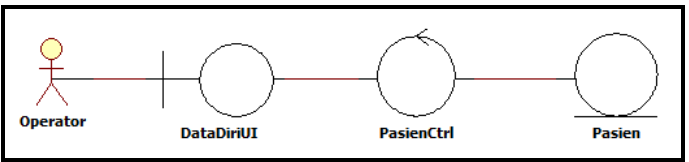

Gambar 5 Analysis Class Diagram Mencatat Data Diri Pasien

Class-class yang terkait pada use case "Mencatat Data Diri Pasien” antara lain :

a) Class Boundary: DataDiriUI

b) Class Control: PasienCtrl

c) Class Entity: Pasien

\subsection{Perancangan}

Realisasi use case tahap perancangan dapat digambarkan dengan class diagram dan sequence diagram. Tabel 2 menunjukkan hasil identifikasi class perancangan dari class analisis pada use case “Mencatat Data Diri Pasien”.

Tabel 2 Identifikasi Class Perancangan Use Case Mencatat Data Diri Pasien

\begin{tabular}{|c|c|c|}
\hline Stereotype & $\begin{array}{c}\text { Class } \\
\text { Analisis }\end{array}$ & $\begin{array}{c}\text { Class } \\
\text { Perancangan }\end{array}$ \\
\hline \multirow{3}{*}{ boundary } & \multirow{3}{*}{ DataDiriUI } & formAddPasien \\
\hline & & formEditPasien \\
\hline & & formDaftarPasien \\
\hline \multirow{4}{*}{ control } & \multirow{4}{*}{ PasienCtrl } & pasienCtrl \\
\hline & & pasienDAO \\
\hline & & $\begin{array}{l}\text { databaseAccess } \\
\text { Library }\end{array}$ \\
\hline & & mysqlDBALibrary \\
\hline Entity & Pasien & pasien \\
\hline
\end{tabular}

Gambar 6 merupakan gambar class diagram yang menunjukkan hubungan antar class dari use case “Mencatat Data Diri Pasien”.



Gambar 6 Class Diagram untuk Use Case Mencatat Data Diri Pasien

Sedangkan salah satu contoh interaksi antar objek pada use case "Mencatat Data Diri Pasien" dapat dilihat pada sequence diagram yang ditunjukkan dengan Gambar 7.

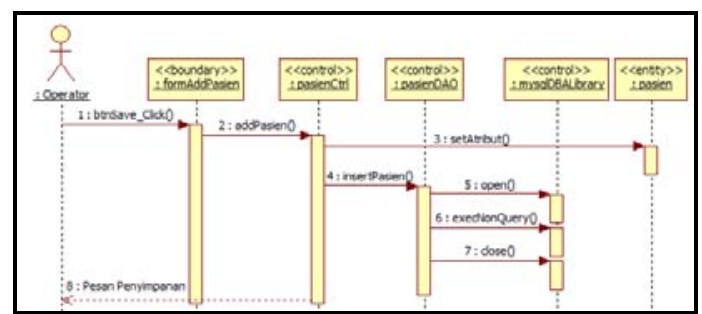

Gambar 7 Sequence Diagram Mencatat Data Diri Pasien\

Rancangan database diperoleh dengan melakukan pemetaan class-class entity ke dalam tabel-tabel pada basis data relasional dengan menggunakan metode ORM (Obeject Relational Mapping). Skema rancangan database dari Sistem Informasi Administrasi Pemeriksaan Pasien di Instalasi Radiologi RSUD Kajen Kabupaten Pekalongan dapat dilihat pada Gambar 8. 


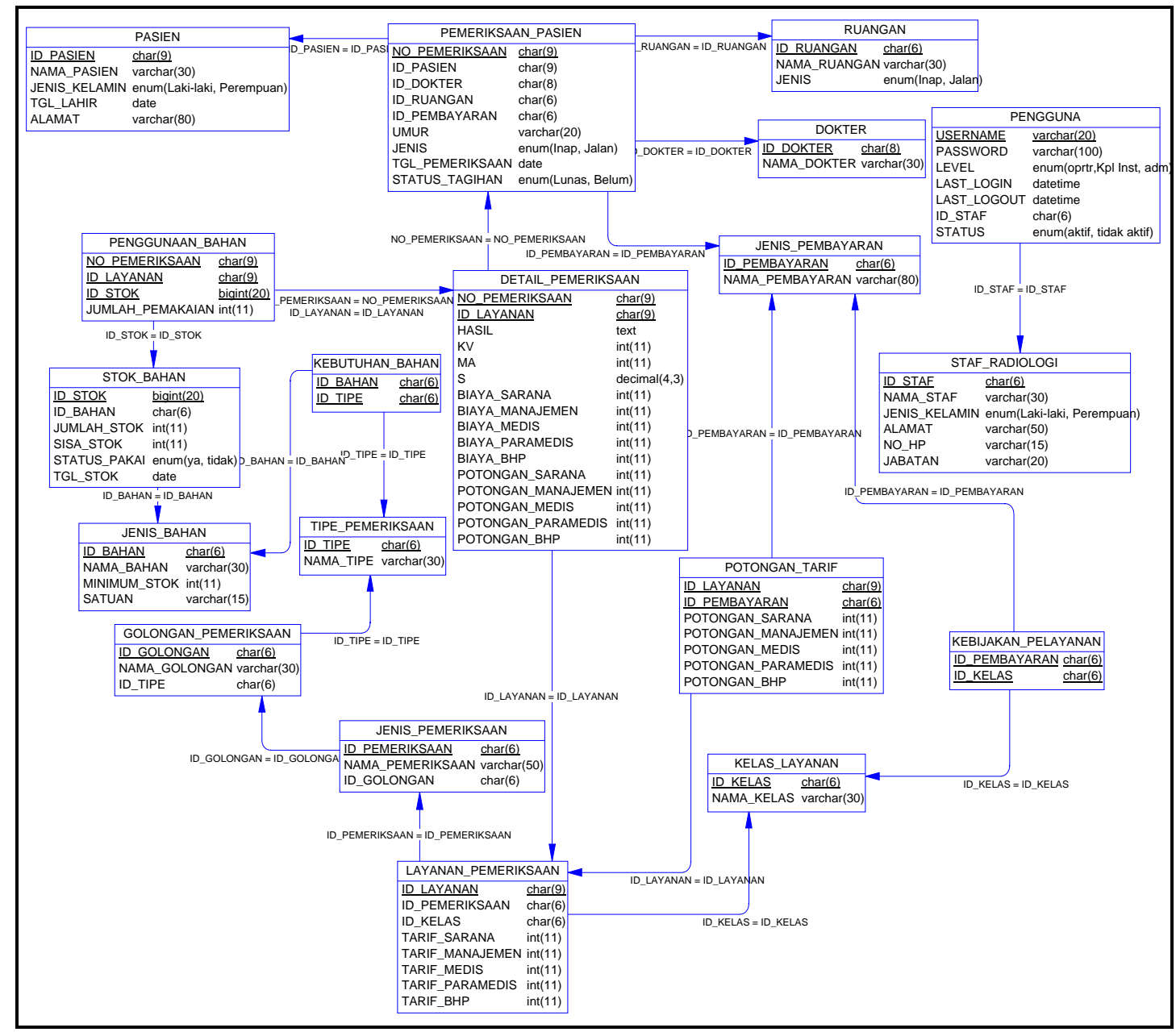

Gambar 8 Skema Database

\section{Implementasi dan Pengujian}

\subsection{Implementasi}

Sistem Informasi Administrasi Pemeriksaan Pasien di Instalasi Radiologi RSUD Kajen Kabupaten Pekalongan diimplementasikan menggunakan bahasa pemrograman Visual Basic .Net dan MySQL 5 sebagai SMBD-nya.

\subsubsection{Implementasi Class}

Implementasi class pada pengembangan Sistem Informasi Administrasi Pemeriksaan Pasien di Instalasi Radiologi RSUD Kajen Kabupaten Pekalongan ini direalisasikan kedalam source code dalam bahasa pemrograman Visual Basic .Net. classclass yang diimplementasikan sesuai dengan stereotype yang telah dirancang pada tahap perancangan.

\subsubsection{Implementasi Antarmuka}

Implementasi antarmuka untuk use case “Mencatat Data Diri Pasien” dapat dilihat pada gambar 9. Operator mengisikan data diri pasien kemudian menekan tombol 'Simpan' untuk menyimpan data diri pasien.

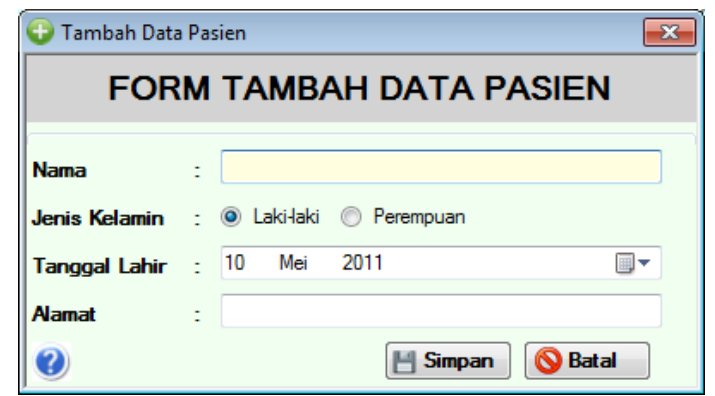

Gambar 9 Tampilan Form Tambah Data Pasien

\subsection{Pengujian}

Pengujian Sistem Informasi Administrasi Pemeriksaan Pasien di Instalasi Radiologi RSUD 
Kajen Kabupaten Pekalongan ini dilakukan dengan metode black box. Pengujian black box diterima jika fitur-fitur yang ada pada perangkat lunak memenuhi spesifikasi kebutuhan sistem atau use case yang telah diidentifikasi sebelumnya.

Dari hasil pengujian menunjukkan bahwa Sistem Informasi Administrasi Pemeriksaan Pasien di Instalasi Radiologi RSUD Kajen Kabupaten Pekalongan ini telah memenuhi untuk :

1) Mencatat data diri pasien yang akan melakukan pemeriksaan radiologi.

2) Menyusun rencana pemeriksaan yang hendak dilakukan pasien.

3) Mencatat penggunaan bahan pemeriksaan.

4) Mencatat hasil diagnosa dokter spesialis radiologi terhadap hasil scan pasien.

5) Mencetak hasil diagnosa dokter melalui media pencetakan yaitu printer.

6) Menghitung tagihan dan mencetaknya melalui media pencetakan yaitu printer.

7) Membuat laporan daftar pemeriksaan pasien.

8) Membuat laporan jumlah pemeriksaan pasien.

9) Membuat laporan jumlah penggunaan bahan pemeriksaan.

10) Membuat grafik jumlah pemeriksaan pasien.

11) Membuat grafik jumlah penggunaan bahan pemeriksaan.

12) Mengelola data layanan pemeriksaan serta mengatur tarif dan potongan tarifnya.

13) Mengatur kebijakan pelayanan pemeriksaan radiologi.

14) Mengatur kebutuhan bahan dari tiap tipe pemeriksaan.

15) Mengelola stok dari bahan pemeriksaan.

16) Mengelola dan mengatur pengguna sistem.

\section{Kesimpulan dan Saran}

Kesimpulan yang dapat diambil dalam pembuatan tugas akhir ini adalah dihasilkan sebuah Sistem Informasi Administrasi Pemeriksaan Pasien di Instalasi Radiologi RSUD Kajen Kabupaten Pekalongan yang dikembangkan dengan Unified Process. Dengan Unified Process, sistem ini dapat dikembangkan lebih lanjut untuk diintegrasikan dengan sistem lain seperti sistem administrasi rumah sakit, sistem kasir rumah sakit, dan sistem-sistem lain yang berada di instalasi lain di RSUD Kajen Kabupaten Pekalongan. Sistem ini dapat membantu pekerjaan para staf radiologi dalam mengelola data pasien beserta pemeriksaannya dan membantu dalam menghitung tagihan pemeriksaan pasien serta menyusun laporan. Dengan adanya sistem ini kinerja para staf radiologi dapat meningkat, sehingga pelayanan terhadap pasien pun semakin optimal.

Sistem Informasi Administrasi Pemeriksaan Pasien di Instalasi Radiologi RSUD Kajen Kabupaten Pekalongan ini sebaiknya dikembangkan lebih lanjut untuk diintegrasikan dengan sistem yang lain seperti sistem administrasi rumah sakit, sistem kasir rumah sakit, dan sistem-sistem lain yang berada di instalasi lain di RSUD Kajen Kabupaten Pekalongan, sehingga sistem ini dapat saling berbagi data dengan sistem-sistem lain di RSUD Kajen Kabupaten Pekalongan.

\section{Referensi}

[1] Ambler S. W., 2002, “Mapping Objects To Relational Databases”.

[2] Arlow J. dan Neustadt I., 2002, UML and The Unified Process Practical ObjectOriented Analisis \& Design, Addison Wesley.

[3] Booch G., Rumbaugh J., Jacobson I., 2005. The Unified Modeling Language User Guide Second Edition. Addison Wesley Professional.

[4] Hermawan B., 2004, Menguasai Java 2 \& Object Oriented Programming, Penerbit Andi, Yogyakarta.

[5] Hunt J., 2003, Guide to the Unified Process featuring UML, Java and Design Patterns, Springer, London.

[6] Jacobson I., Booch G., dan Rumbaugh J., 1999, The Unified Software Development Process, Addison Wesley.

[7] Jogiyanto, 2003, Sistem Teknologi Informasi, Penerbit Andi, Yogyakarta.

[8] Kusumo A. S., 2006, Pemrograman Visual Basic 2005, Elex Media Komputindo, Jakarta. 
[9] Poerwadarminta W. J. S., 1984, Kamus Besar Bahasa Indonesia, PN Balai Pustaka, Jakarta.

[10]Pressman R. S., 2001, Software Engineering : A Practitioner's Approach Fifth Edition, McGraw - Hill, New York.
[11] Sholiq, 2006, Pemodelan Sistem Informasi Berorientasi Objek dengan UML, Graha Ilmu, Yogyakarta.

[12] Valade J., 2010, PHP and MySQL For Dummies, 4th Edition, Wiley Publishing, Inc., Indiana. 